\title{
Sociological Theorising and Contemporary Social Problems in Nigeria
}

\author{
Dr. Ogaga Ayemo Obaro \\ Department of Sociology and Anthropology \\ Faculty of Social Sciences, University of Benin, Benin City, Nigeria. \\ E-mail: ogagaobaro@yahoo.com and josefenoch@gmail.com
}

\section{Doi:10.5901/mjss.2014.v5n2p541}

\begin{abstract}
This paper seeks to survey some of the larger domains of social thinking with which concerns about social problems intersect; to offer an account of some themes in social theory that are having or may come to have a bearing on the study of social problems. It has been suggested that to 'theorise' about any topic of importance in human science is to attempt to develop "responsible speech" about it. In such a short space, it is impossible to give anything remotely approaching a full account of any of the various theoretical positions in question. The paper can only present enough on each only to indicate why it views theoretical positions as relevant and interesting. Even so, it has restricted the range of perspectives covered to the point where it can give a brief exposition on each and develop at least the outline of a connected argument. Nevertheless, it is also in the very nature of theoretical discussion that it selects and defines its objects, and reflects on ways of generating knowledge about them. In this sense, all theoretical work however large its scope and ambition, remains partial and restricted in character.
\end{abstract}

Keywords: Contemporary, Problems, Sociological, Social, Theorising,

\section{Introduction}

All theoretical work however large its scope and ambition remains partial and restricted in character (Mouzelis 1995: 12). Bauman suggests that to 'theorise' about any topic of importance in human science is to attempt to develop "responsible speech" about it (Bauman 1990:12). Theories of society, of social problems and of social policies are interrelated. However, the link running through the explanations of these phenomena may not always be obvious, nor does the relationship always correspond perfectly, but nevertheless exist to lesser or greater extent. The compartmentalization of social science into separate disciplines has helped to obscure this inter-relationship, for each specialist discipline tends to be primarily concerned with its own domain, with little reference to knowledge beyond its boundaries. This has been particularly true of social administration, partly because of its heavy concentration on pragmatic, empirical studies of social problems and social policies with little emphasis on social theory. Sociology on the other hand has until recently shied away from studying social problems from a reform prospective for fear of tarnishing its image of scientific objectivity with the unscientific value judgment which are unavoidable in the area of social problems and social policy (George and wilding,1976:1-2).

\section{Definition of Social Problems}

Various definitions of social problem abound in text books of sociology, social problems and social administration. A few of them may suffice for the scope of this paper. To the understanding of Kornblum and Julian, when most people in the society agree that a condition exists that threatens their life and their most cherished values and also agree that something should be done to remedy that condition, sociologies say that the society has defined that condition as a social problem (Kornblum and Julian,1995:3). According to Horton, Leslie and Larsons, a social problem is a condition affecting a significant number of people in a society in ways considered undesirable and about which it is felt something should be done through collective or social action (Horton, Leslie and Larsons, 1991:2). Lauer clarified social problem by distinguishing between a personal problem and a social problem. A personal problem is one whose causes and solutions lie within the individual and the individual's immediate environment; while a social problem is one whose causes and solution lie outside the individual and the immediate environment (Lauer, 2002:4).

C. Wright Mills made a similar distinction, calling personal problems the "personal troubles of milieu" and social problems the "public issues of social structure" (Mills, 1980:14-15). In the view of Nwabueze, social problems are object 
conditions within society that are inimical to the realization of other norms and values for members of society (Nwabueze, 1992). Merton and Nisbet distinguish social problems from other problems by their linkage with institutional and normative context. Social problems pertain to human relationships. Problems assume a social dimension when they affect relationships among people and disturb the social order (Merton and Nisbet, 1966). But a rather more inclusive or comprehensive definition asserts that a social problem exists when a significant number of people or a number of significant people in society perceive an undesirable difference between social ideas and social realities, and believe that this difference can be eliminated by collective and social actions (Aderinto, 2002:337).

What is important in all these definitions is that the majority or a significant number of the society's population, or a number of significant (or powerful) people in the society perceive a certain social condition as undesirable or inimical to normal social life, and there is also a willingness or longing for the "abnormal" social condition to be ameliorated to ensure that most of the people adversely affected are helped at public expense to get over it. Emphasis is placed on society recognizing a condition as problematic and then acting through the government for its solution. This is partly a matter of objective knowledge and partly a subjective question of power relations, ideologies, values, and the availability of the means to solve the problem. The situation or condition of individuals or groups is defined as representing need or as social problem and calling for collective, public, social policy or action in the light of different convictions about the kind of political, economic and social relations that are desirable in society. However, great inequalities in living conditions and in opportunities, as well as, absolute destitution are held to justify government intervention to ameliorate social problems.

In a nut shell, for a social problem to be seen as such, it must be an objective condition or a subjective perception of that condition as a social problem. A significant number or a number of significant people in society must see the condition as affecting the rule of human relationship and hampering orderly living in the society. Besides, there must be seen a demonstrable desire, decision, determination and discipline to ameliorate the problematic social condition. In this case, the role of government, powerful people, pressure groups, public opinion and media publicity are seen to be of great influence in the labeling or definition of condition as social problem.

\section{Some Social Problems in Nigeria}

Most people will no doubt agree that we can readily identify the current campaigns against women trafficking and prostitution, child trafficking and labour, harmful traditional practices such as female genital mutilation, early marriage, widow inheritance, gender discrimination, HIVIAIDS, endemic and deepening corruption, bad governance, abusive security forces, poverty, unemployment, illiteracy, injustice, minority marginalization, internal colonization by national dominant groups in league with globalizing capital, growing inequalities between the rich and poor, insecurity, crime, violence, terrorism, pollution, urban decay, lack of basic hygiene, spread of incurable diseases, ethnic cleansing and deteriorating education are examples of both objective conditions and subjective perceptions of our society's most pressing social problems. Of course, our final list of social problems would depend to large extent on where we live and what issues affect our lives most immediately. These problems inhibit the development of society. Moreover, these problems are related to each other and it can seem hard to address one without addressing all of them. It would be erroneous to assume that a social problem only affects the people whom it directly touches, but this is not the case. Easy spread of disease for instance may tamper with the society at large. The spread of AIDs for instance has created more social problems because it is costly, it is a danger to all members of society, and it leaves many children without parents. HIVIAIDs is not a single problem but a complex cause of numerous ones. Similarly, unemployment in Nigeria doesn't just affect those unemployed but affects the whole economy.

\section{Social Problems as Sociological Problems}

One of the most widely held belief about sociologists is that their business is finding solution to social problems. Very often, of course, it is. The root of modern sociologist is traceable to the large scale societal disorganization, which followed the wake of turbulent American, French and industrial revolutions. Sociology, therefore, grew out of compassion and a desire to solve the social problems of these revolutions and /or change the world for the better (Worsley, 1981; Easthope, 1974; Berger, 1977). It is no wonder therefore, that early interest in sociology in Britain and America was based on concern for the poor: with the social causes and effects of poverty, ill-health, poor housing, unemployment, crime and delinquency. These problems and more are easily found in any industrial, urban or modern society, and considerable opposition to modern life is based on problems and difficulties people face (Peil, 1977:304).

But a sociological problem is not the same as a social problem. Two most useful distinctions with which the 
sociological imagination works are between a sociological problem and a social problem, and between a personal problem and a social problem. In the first distinction, a sociological problem occurs when there is a need to explain social behavior in terms of sociological theory; and a social problem occurs when social behaviour causes misery or is miserable and needs collective action to solve it. Nevertheless, by looking at social problems as sociological problems, it may help to arrive at a better understanding of why and how social problems occur (Worsley, 1981:11).

The second distinction is between personal problem and social problems. This is also an essential tool of the sociological imagination. Personal problems occur within the character of the individual and with those limited areas of social life of which he is directly and personally aware. Accordingly, the statement and resolution of personal problems properly lies within the individual as a biographical entity and within the scope of his immediate social setting that is directly open to his personal experience and to some extent, his willful activity. A personal problem is a private matter or problem. On the other hand, social problems have to do with issues or matters that transcend the local or immediate environments of individuals. A social problem, in fact, often involves a crisis of institutional arrangements, and often too, it involves what Marxists call 'contradictions' or 'antagonisms'. Social problems occur within structures and processes of social and historical life of a society (Mills, 1980: 14-15; Lauer, 2002:4). In other words, social problems though may be things that happen to particular people, they are often not unique experiences: they are personal in their impact, but patterned both in their causation and distribution.

For any one, social problem debates may arise over their causes and extent. Some might argue, for example, that people who are sexually promiscuous or use drugs intravenously bring their troubles upon themselves. But others might point out the consequences of AIDS and other illnesses are problems that should concern everyone. These and similar arguments deal not only with the causes of social problems but also with what should be done about them.

Of course, agreement that remedies are necessary does not imply that people agree on what the remedies should be. In short, recognition that a social problem exists is far different from arriving at a consensus about what to do about the problem. All social problem are product of a process of definition, and an understanding of what is defined as a social problem, how it is defined and who does the defining, as well as, what social legislation, social policy or social action is taken, and who shapes social legislation, policy or action is clearly crucial to the understanding of social problem (George \& Wilding 1976; Becker, 1963).

It must be insisted that sociology is concerned with the normal as well as the abnormal; with happy families as much as 'problem families'; with the everyday as well as the exotic; and with virtue as much as vice. Hence, as sociologists, we are concerned with both sociological problems and social problems, for we have to explain theoretically how it is that societies persist and change. By looking at social problems as sociological problems, we may then be better able to see that apparently purely personal problems, such as poverty, sickness, loneliness, criminal behaviour, HIVI AIDS, and so on are part of general social processes that afflict thousands in similar life situations (Worsely, 1981:12; Mills, 1980:15).

\section{Sociological Theories of Social Problems}

Contemporary sociology is found on three basic theoretical perspectives or sets of ideas that offer theories about how and why society persists and how and why they change. These perspectives are not the only sociological approaches to social problems, but they can be extremely powerful tools for understanding such problems. Each of these perspectives, for example, functionalism, conflict and interactionism gives rise to a number of distinctive approaches to the study of social problems.

\subsection{Functionalist Theory}

The central features of sociological functionalist theories of society are from the point of view of this discussion, the stress on order, consensus, stability, integration and functional relations (Dahpendorf, 1959:161). The functionalist theory looks at the way social institutions like the family, education, economy, polity, religion and their sub-systems function. Functionalist sociologist do not focus on the behaviour and problems of individuals, instead they see social problems as arising out of the failure of institutions of society, like the family, education, economy, polity, and religion to adapt to changing social conditions. Every part or institution of society is seen as having a function in the sense that it contributes to the smooth running of the society. Hence, when one part of the society is out of the line with the others, there is pressure for its reintegration with the other related parts. In this way, stability in society, by and large, prevails. It is not only stability based on functional necessity but stability based on consensus of values. Individuals in society, according to 
this theory, share the same basic values and are thus agreed on the way they behave towards each other as individuals or as members of groups. Shared values and moral judgments lead to general agreement about modes of behaviour in society. Thus, the value system of society is, according to Parsons, "the sets of normative judgments held by members of the society who define, with specific reference to their own society, what to them, is a good society..." (Parsons, 1969:9)

With all these qualifications, it is still true to say that values held in common constitute the primary point for the analysis of a social system as an empirical system (Parsons, 1969:9). This general agreement on social values which leads to agreement on behaviour patterns results in a stable, integrated society, which is perpetual from generation to generation through the two basic social processes of socialization of the young and social control of everyone (Parsons, 1952:227). As Lockwood rather harshly observes in his critique of Parson, "the two major threats to a given social system are infants who have not been socialized and individuals who are motivated to deviance or non-conformity (Lockwood, 1956).

Clearly a view of society that emphasizes stability, order, equilibrium, consensus, and the functional relationship of the various parts of institutions of the society will tend to see social problems either as problems of deviance or as problems of social disorganization. The essential difference between the two types of problems is that "the types of social problems involved in disorganization arise not from people failing to live up to requirement of their statuses, as in the case of deviant behaviour, but from the faulty organization of social statuses into a reasonable coherent social system" (Nisbet \& Merton, 1966:804). The main sources of social disorganization are "breakdown in channels of effective communication between people of a social system", "defects in the processes of socialization", and "faulty arrangement of competing social demands upon people" (Kornblum \& Julian, 1995:8-9).

It is also acknowledged that disorganization and deviance are related and under certain circumstances they can induce each other. Most social problems are thus seen as the product of the interacting forces of both disorganization and deviance. Thus, poverty among the population of working age in advance industrial societies has been divided by Galbraith into insular and case poverty (Galbraith, 1970:260-2). The first is the result of heavy unemployment in declining regions of the country, that is, it is the result of social disorganization. It is the absence of jobs or the inability of declining industries to pay adequate wages that make it impossible for people to fulfill their statuses rather than the failure of individual to find a job or to work hard. The second is the result of some peculiar characteristics of the individual, that is, lack of training, low education standard, excessive procreation, laziness, and so on. Not only is some poverty the result of disorganization and other poverty the result of deviance, but conditions of disorganization can lead to condition of deviance with the result that it is not always possible to tell whether a person who is poor is deviant or disorganized.

The disorganization-deviance thesis, theory, or hypothesis of social problems has dominated social science literature (George \& Wilding, 1976:6; Ryan, 1971:7, 27). Many social problems are seen as having little relationship with economic or political inequality and other as having none. Thus their solution is not seen to be directly opposed to vested economic interests in the society. Emphasis is placed on 'society' recognizing conditions as problematic and hence acting through the government for the solution or amelioration of social problems in a collective, gradual, piecemeal way without disturbing the existing structure of the society.

The functionalist theory of deviance-disorganization can be fruitfully used in the study of such current problematic condition in Nigeria as, criminality, violence, as well as, poverty, unemployment, population problem, problem families, environmental degradation and pollution, and homelessness, and insecurity. Social disorganization theory, linking (directly) crime rates to neighborhood ecological characteristics, youths from disadvantaged neighborhoods were participants in a subculture in which delinquency was approved behavior and that criminality was acquired in social and cultural settings through a process of interaction. A core principle of social disorganization theory is that place matters (one's residential location) as much or more than one's individual characteristics (age, gender, race) in shaping the likelihood that a person will become involved in illegal activities. According to the social disorganization theory, there are ecological factors that lead to high rates of crime in these communities, and these factors linked to constantly elevated levels of high school dropouts, unemployment, deteriorating infrastructures, and single-parent homes. The theory is not intended to apply to all types of crime, but instead to street crime at the neighborhood level. The theory has not been used to explain organized crime, corporate crime, or deviant behavior that takes place outside neighborhood settings (Kubrin \& Weitzer, 2003).

\subsection{Conflict Theory}

By no means do all sociologists accept the functionalist view of society and social problems. There is an alternative set of theories, often known as the conflict perspective that rejects the idea that social problems can be solved by reforming 
institutions that are not functioning well. The conflict approach is based on the belief that social problems arise out of major contradictions in the way society is organized; contradiction that lead to large-scale conflict between those who have access to the "good life" and those who do not. This perspective owes much to the writing of Karl Marx. In "The communist Manifesto" and "capital" and other works, Marx attempted to prove that social problems like unemployment, poverty, crime, corruption, conflict and violence, and so forth, are not usually the fault of individuals or of poorly functioning organizations. An evitable outcome of capitalism is class conflict, especially conflict between those who own the means of production and those who sell their labour for wages (Marx, 1867; Marx \&Engels, 1848).

Conflict is a fact of life in modern industrial societies. Conflict theories of society are overshadowed by the Marxist approach in the same way that consensus theories are dominated by the Parsonian approach. It is indeed quite possible, Coser demonstrates, to accept consensus model of society which incorporates conflicts (Coser, 1956). In a model of this kind conflict is seen as having such "positive function" as reducing tension in society, or preventing tensions from building up to violent explosive degrees, making internal changes possible and thus preventing ossification of social structures and so on. Seen in this perspective, social conflict has a cathartic and hence an invigorating effect on social system. It does not alter the social system itself but it makes changes within the system, which renders it more effective and spritely.

The Marxist theory of class conflict has more fundamental implications for the social system than theories which restrict themselves to group types of conflict. This is because class conflict centers around the economic relations in society, which Marxists claim, are the basis of the other types of relationship in the society. Changes in the economic system bring about changes in the social, political and ideological system of the society. Class conflict is seen as natural and inevitable in a stratified society. It is the vehicle of fundamental changes in the whole social system of society. It is basic to the transformation of capitalist society to socialism. Society is seen not as a stable integrated structure but as conflict-ridden and always changing. Power is distributed unequally in society with the result that the wicker social group, though they form the largest segment of the population, come to accept, in practice if not in theory, their subordinate position. This is effected through a variety of processes: coercion, economic dependence, the legitimation of dominant social values, rising economic affluence, and welfare state provisions. Class conflict in society is reduced and radical change is either contained or slowed down or diluted.

Marxist theories give little attention to the sociological processes which generate social problem. They generally rely on the contributions of other conflict theorists who tend to view the main social problems of contemporary industrial societies as been essentially the product of the conflict of the economic interests between the two main social classes and between smaller groups in society. In other words, the problem of poverty, unemployment or criminal deviance is regarded neither as the result of cultural deviation by the poor or criminals from society's accepted values and norms, nor as the result of social disorganization nor as the consequence of some dysfunction in the society. Rather, it is seen as the result of the economic exploitation of one group in society by another (Marx, 1848, 1867). The Marxists believe that solving the problem of poverty, unemployment or criminality must affect the economic position of the rich and the nonpoor in society. They argue too that labeling such potential conflict situations as social problems helps to defused them for it tends to defuse responsibility for their existence and continuance and leads to a search for solution which does not affect the existing distribution of wealth, income and power.

From the Marxian conflict perspective, the rich and powerful are able to determine what kind of behaviours are defined as social problems. They are also able to shift the blame from the conditions that produce those problems to groups in society that are less able to defend themselves, namely, the poor and powerless (Balbus, 1978; Quinney, 1978; Turk, 1978).

Scholars who adopt a Marxian conflict perspective tends to be critical of proposals to reform existing institutions, since they attribute most social problems to underlying patterns of class conflict. Usually, therefore, their research looks at the ways in which the material conditions of society, such as inequalities of wealth and power seems to account for the distribution of social problems in a population. Or they conduct research on social movements among the poor and the working class in an attempt to understand how those movements might mobilizes large numbers of people into a force that could bring about major changes in the ways society is organized (Piven \& Cloward, 1977, 1982).

However, the Marxian theory of class conflict alone cannot explain all kinds of social problems that occur around us. They are also value conflict theorists who define social problems as "conditions that are incompatible with group values" (Rubington \& Weinberg, 1971; 86). According to value conflict theory, social problem occur when groups with different values meet and compete. Such problems are normal, since in a complex society, there are many groups whose interests and values are bound to differ and/or conflict. From the value conflict viewpoint, many social problems need to be understood in terms of which groups hold which values and have the power to enforce them against the wishes of 
other groups.

Thus, the conflict theory of class-value conflict can be a powerful tool for analysing contemporary social problems in Nigeria, such as, criminality, corruption, poverty, inequalities of opportunities and quality of life, and social conflict such as, class, value, ethnic and communal, religious, political, industrial and labour conflicts.

\subsection{Interactionist Theory}

Interactionist theory offers an explanation which gets us closer to the individual level of behaviour. Research based on this perspective looks at the processes whereby different people become part of a situation that the larger society defines as a social problem. The interactionist approach focuses on the ways in which people actually take on the values of the group of which they are members. It also explore how different groups define their situation and in so doing "construct" a version of life that promote certain values and behaviours and discourages others. From the interactionist perspective, an individual or a group's definition of the situation is central to understanding the action of that individual or group: "situation people define as real", Thomas stated, "are real in their consequences" (Thomas, 1923:41-44).

Above all, labelling theory is a major application of the interactionist perspective that offers an explanation for certain kinds of social problems. Labelling theorists feel that the label "deviant" or "poor" reveals more about the society applying it than about the act or person being labelled. In the view of labelling theorists, their definition has to do with the way power is distributed in society. Accordingly, social problems are conditions under which certain behaviours or situations become define as social problems. The cause of a social problem is simply society's awareness that a certain behaviour or situation exists. The way to solve social problems, according to labelling theory, is to change the definition of what is consider as social problem (Rubington \& Weinberg, 1971).

The interactionist perspective of the "definition of the situation", peer group interactions and labelling can be related or applied to the understanding of some current problems in Nigeria, which include: crime and delinquency, violence, human trafficking, prostitution, drug abuse, child abuse, prejudice and discrimination, corruption, and insecurity.

\section{Theoretical Framework}

It is possible to consider social problems within the theoretical framework that adopts a continuum of social problems ranging from those which are primarily conflicts of moral values to those which are primarily conflicts of economic interest. These are ideal types and though, all social problems will involve conflict of both moral values and economic interest, some will be more easily placed at one end of continuum than the other. Other problems will belong to middle part of the continuum, and for some others, there will be disagreement as to their proper classification.

Functionalist, conflict and interactionist theories differ in the way they view social problems. Functionalist theories of society tend to consider behaviour, which depart from conventional standards as problematic, for not only do they assume a uniformity in the values and norms of society, but they also consider that such behaviour as is generally accepted is best. Conflict and interactionist theories of society, on the other hand, accept greater cultural diversity in society and they tend to question the legitimacy of generally accepted form of behaviour. Seen from the conflict and interactionist perspective, concern for social problem is tantamount to concern about the social system itself. The study of social problem is, as Sykes has written " nothing less than the study of what is considered the satisfactory and unsatisfactory organization of society, not in terms of mirror concerns arousing momentary public indignation, but in terms of the major elements of the social structure" (Sykes, $1971: 9-10)$.

At the other end of the continuum are those problems which are produced primarily by conflicts between value systems of the particular group concerned and of the rest of society. Abortion for example involves conflict of moral values and behaviour between those who accept abortion and those who do not. At the same end of the continuum is another group of social problems which are the result of physical or mental malfunctioning which challenges the ethical value system of society, for example, deafness, blindness, mental handicap and so on. They are the product not of conflicts between the value system of the particular group and rest of the society but rather the conflict between the problematic situation of the group in question and social ethical value system. The inability of such groups to live a normal life without help and the ability of their fellow citizens, if they so wish, to "normalise" their lives, make their situations challenging to certain ethical values.

Many social problems will be plotted in the continuum for they involve conflicts of economic interests and value system fairly equally. The approach to social problems being suggested also recognises the existence of conflicting value 
systems and forms of behaviour without necessarily apportioning blame and moral worthlessness. It is a more open and realistic approach to social problems involving conflict of value systems and it may perhaps lead to a more understanding attitude toward groups whose value systems and behaviour are different from those of the majority in society. It goes without saying, however, that even in a socially just and egalitarian society, where economic domination and exploitation will either cease or substantially reduced, there will be problem of value conflict, and social problem of this type are part and parcel of life in society (George \& Wilding, 1977).

\section{Conclusion}

There is general agreement among social scientists that the definition of a situation as a social problem is related to the power structure of society (Merton \& Nisbet, 1966:785). Social definitions of social problems have this in common with other processes in society: those occupying strategic positions of authority and power of course carrying more weight than others in defining social problems and therefore, among other things, in deciding social policy direction. Social problems are the product of the process of definition, and social policies are a product of legislation. An understanding of who does the defining of what is defined as social problem and how it is defined, as well as, who shaped legislation and in what ways, is clearly crucial to the sociological perspective on social problems.

If power is concentrated in the hand of the ruling class, as the Marxist maintain, then the definition of what officially constitute a social problem, particularly one that is essentially a conflict of economic interest between social classes, will be the domain of the ruling class and its allies. There may, of course, be other definitions of the same problem, but for social policy measures, it is the ruling class definition that counts. There may also be situation where economic interests are directly involved and where the conflict of definition is between groups other than social classes. Nevertheless, social class is a determinant of what is defined as social problem in the crucial areas. Ross \& Staines refer to this relationship between social class and social problems as follows:

Despite the creation of many status Graduation in a complex technological Environment, economic class still provides Some of most obvious examples of the Linkage between group membership and Problem perception ... (Ross \& Staines, 1972).

If social problems are the product of conflict, then attempts to solve them are primarily attempt to reconcile conflicting economic interests and value systems. Social policy is primarily the result of the constant attempt of various groups in the society to improve or redefine their situations, vis-a-vis those of other group (Rex, 1061:127-9).

Very often too, we see many instances of interconnections among social problems. Therefore, when we seek solution to social problems, we must consider multi-faceted approaches that address entire sets of problems rather than a single problem by itself, a situation that makes the formulation of social policy quite difficult, but challenging.

\section{Policy recommendation}

1. Reorganization of people's lives to cope with problematic conditions through improvement in organizations and social institutions in the Nigeria society.

2. Social policies should focus on the ways in which the material conditions in the Nigerian society, such as inequalities of wealth and power seem to account for the distribution of social problems in the population.

3. Organization and mobilisation of the poor and working people into a social movement that could bring about major positive or progressive changes in the way society is organised.

4. Resolution of conflicts through negotiations and settlements that will alleviate the conflicting or problematic conditions.

5. Arbitration of disputes, open hearing on issues in conflicts and changes in existing laws and policies to reflect diversity of opinions in the Nigerian society.

6. The Nigerian society should decriminalise minor crime and discourage the tendency to impose labels for gain and cause formal problems to become less significant, especially, when it becomes clear that label is being misapplied and the fear it generates is unjustified.

7. Society should explore the possibility of intentional re-socialisation through group interaction in efforts to address social problems. 


\section{References}

Aderinto, A.A. (2002), "The concept of social problem", in U.C.Isiugo-Abanihe, A.N. Isamah and J.O. Adesina. Eds., Currents and Perspectives in sociology, Lagos: Malthouse press limted, Pp.337.

Balbus, J. (1978), "Commodity form and legal form. An easy on the relative anatomy of the law" in C. E. Reasons and R.M.Rich, eds. Sociology of Law: A Conflict perspective, Toronto: Butterworths.

Bauman, Z. (1990), Thinking sociologically, Oxford : Blackwell, Pp. 12.

Berger, P.L. (1977), Imitation to sociology: A Humanistic Perspective, penguin Books.

Coser, L. (1956), "The Function of Social Conflict". Routledge \& Kegan Paul.

Dahrendorf, R. (1959), "Class and Class Conflict in Industrial Society". Routledge \& Kegan Paul, Pp. 161.

Easthrope, G. (1974), A History of Social Research Methods, LoTdon: Longman.

Galbraith, J.K. (1970), "The Affluent society", Penguin, $2^{\text {nd }}$ ed., Pp. 260-2.

George, V. and Wilding, P. (1976), Ideology and Social Welfare, London: Routledge \& Kegan Paul,

Gusfield, J.R. (1975), "The (F) utility of Knowledge?: The Relation of Social Science to Public Policy Towards Drugs", Annals of the American Academy of Political and Social Sciences, 417;1-15.

(1981), The Culture of Public Problems: Drinking, Driving and the symbolic order, Chicago: university of Chicago press.

Horton, P.B., Leslie, GR., Larson, R.F.(1991), The Sociology of Social problems, 10th edn., New Jersey: Englewood cliffs, Pp.2

Janowitz, M. (1971), Institution Building in Urban Education, Chicago: University of Chicago Press. (1978), The Last Half Ccentury: Soccietal Change and politics in America,

Chicago: University Chicago Press.

Lauer, P.H. \& Laner, J.C. (2002), Social Problems and the Quality of Life, $8^{\text {th }}$ ed., New York: McGraw-Hill.

Kornblum, W. \& Julian, J. (1995), Social Problems, New Jersey: prentice- hall, inc. Ch.1.

Lockwood,D. (1956),Some remarks on 'The Social System', British Journal of Sociology, vol. vii, No.2.

Kubrin, C. \& Weitzer, R. (2003). "New Directions in Social Disorganization Theory". Journal of Research in Crime \& Delinquency 40: 374-402.

Marx, K. \& Engels, F. (1848), The Communist Manifesto, Baltimore, MD: Penguin BOOks, 1969.

Marx, K. (1867), Capital: A Critique of Political Economy, Moscow: Foreign Languages Publishing House, 1962.

Mills, C. W. (1980), The Sociological Imagination, Penguin Books, Pp. 44

Mouzelis, N. (1995), Sociological theory: what went wrong?; London: Routledge, Pp.44.

NIsbet, R.A \& Merton, R. K. (1966), 'Contemporary Social Problems', Harcourt, Brace \& World, Pp.785, 804.

Nwabueze, N. (1992), "The Nature of Social Problems and Social Policy "in N.Nwabuese and F.D Oyekanmi, eds., Social Problems and Social Policy in Nigeria, Lagos: Osko Associates.

Parsons, T. (1951), "Towards a General Theory of Action", Howard University Press, Pp. 227. (1969), "Sociological Theory and Modern Society". Free Press, Pp. 6.

Peil, M. (1977), Consensus and conflict in African Societies, London: Longman Pp 304.

Piven, F.F. and Cloward, R.A. (1977), Poor People's Movements: Why They Succeed, How They Fail, New York: Pantheon Books. -- (1982), The New Class War: Reagan's Attack on the Welfare State and its consequences, New York: Pantheon Books, Pp. 6.

Quinney, R. (1978), "The ideology of Law: Notes for a Radical Alternative to legal oppression", in C. E. Reasons and R. M. Rich, eds; Sociology of Law: A Conflict perspective. Toronto: Butter Worths.

Rex,J. (1961), 'Key Problems of Sociological Theory', Routledge \& Kegan Paul, Pp.127-9.

Ross, R. \& Staines, G.L. (1972), The politics of Analysing Social Problems, 'social problems', Vol. 20, No. 1.

Rubington, E. \& Weinberg, M. S. eds. (1971), The study of Social Problems: Five perspectives, New York: Oxford University Press.

Rules, J.R. (1971), The Problem with Social Problems. Politics and Society, Vol. 2, No. 1.

Ryan, J.R.(1971), "Blaming the Victim", Orbach \& Chambers, Pp. 2,27.

Sykes,G.M.(1971), 'Social Problems in America; Foresman, Pp. 9-10.

Thomas, W.I. (1923), The Unadjusted Girl, Boston: Little Brown, Pp.41-44.

Turk, A.T. (1978), "Law as a Weapon in Social Conflict", in C.E. Reasons and R.M. Rich, eds., Sociology of Law: A Conflict Perspective, Toronto: Butterworths. Vol .20, No.1.

Worsley, P. ed. (1981), Problems of Modern Society: A Sociological Perspective, 2nd ed., Penguin Books, Pp.11-12. 